\title{
A simple and efficient dual optical signaling chemodosimeter for toxic $\mathbf{H g}$ (II)
}

\author{
Sabir H. Mashraqui ${ }^{*}$, Sapna A. Tripathi, Sushil S. Ghorpade \\ and Smita R. Britto
}

Open Access

\author{
Full Research Paper \\ Address: \\ Department of Chemistry, University of Mumbai, Vidyanagari, \\ Mumbai-400098, India \\ Email: \\ Sabir H. Mashraqui* - sh_mashraqui@yahoo.com \\ * Corresponding author \\ Keywords: \\ chemidosimeter; chemosensor; fluorescence; $\mathrm{Hg}(\mathrm{II})$ selective; \\ UV-visible; visual detection
}

\author{
Beilstein J. Org. Chem. 2012, 8, 1352-1357. \\ doi:10.3762/bjoc. 8.155 \\ Received: 07 May 2012 \\ Accepted: 20 July 2012 \\ Published: 22 August 2012 \\ Associate Editor: J. A. Murphy \\ (C) 2012 Mashraqui et al; licensee Beilstein-Institut. \\ License and terms: see end of document.
}

\begin{abstract}
10-Methylthioacridone, designated as acrithion, has been employed as an easily accessible chemodosimeter for the optical targeting of toxic $\mathrm{Hg}^{2+}$ in buffered aqueous DMSO. The $\mathrm{Hg}^{2+}$-mediated desulfurization of the probe is translated into selective dual signaling of $\mathrm{Hg}^{2+}$ by means of color bleaching and fluorescence amplification while several other metal ions, including potentially competing $\mathrm{Ag}^{+}, \mathrm{Cu}^{2+}$ and $\mathrm{Pb}^{2+}$, afford no significant interferences even in excess concentrations.
\end{abstract}

\section{Introduction}

Interest continues unabatedly to design optical probes for the selective detection of metal ions of importance across disciplines of biology, medicine and environment [1-5]. Though, mercury and alkylmercury are highly poisonous, mercury ions are also a subject of worldwide concern because of their acute immune-, geno- and neurotoxic effects on human, livestock and marine mammals [6-11]. The poisonous effects of mercury ions stem from their irreversible binding with the sulfhydrylcontaining groups of proteins and enzymes, resulting in clinical problems such as prenatal brain damage, muscle coordination difficulties, lung, kidney and vision disorders.

To date, many chemosensors featuring assortments of ligands and signalling units have been reported for the detection of potentially toxic metal ions such as $\mathrm{Cu}^{2+}, \mathrm{Hg}^{2+}, \mathrm{Pb}^{2+}$ etc. However, owing to the reversible coordination with the probes, these paramagnetic metal ions often result in less desirable fluorescence quenching effects [12-16]. Lately, the chemodosimeter-based sensing has gained increasing popularity on account of the irreversible chemical intervention of analytes with the probe molecules. Since the metal ions are disengaged from the chemically modified dosimeters, the process results in the more reliable fluorescence ratiometric or switch-on responses even for the paramagnetic metal ions [17-19]. The first luminescence chemodosimeter for $\mathrm{Hg}^{2+}$ was developed by Czarnik et al. and was based on the $\mathrm{Hg}^{2+}$-mediated desulfurization of anthracene-thioamide chromophore [20,21]. Following this pioneering report, several other groups have utilized the 
exceptionally strong thiophilicity of $\mathrm{Hg}^{2+}$ to access a range of luminescent $\mathrm{Hg}^{2+}$ chemodosimeters [22-38]. Despite impressive advances $[39,40]$, many known $\mathrm{Hg}^{2+}$ chemosensors suffer from multistep syntheses and delayed responses or cross affinities, especially from $\mathrm{Ag}^{+}, \mathrm{Pb}^{2+}$ and $\mathrm{Cu}^{2+}$ [41-51]. Consequently, designing easily accessible $\mathrm{Hg}^{2+}$-selective chemosensors with dual colorimetric and fluorescence switch-on capabilities is deemed of interest in supramolecular research.

Acridone, a photostable fluorophore [52], has been designed to function as metal ion and anion sensor [53-57]. In contrast to moderately fluorescent acridone, its thione analog is poorly emissive presumably on account of the intersystem crossing process of the $\mathrm{C}=\mathrm{S}$ bonding [58]. Keeping this in mind, we have presently conceived the design of simple and easily accessible 10-methylthioacridone - designated as acrithion $\mathbf{2}$ - as a new chemodosimeter for the highly selective colorimetric and fluorescence signaling of $\mathrm{Hg}^{2+}$.

The chemodosimeter mechanism, illustrated in Scheme 1, is proposed to proceed via chelation of $\mathrm{Hg}^{2+}$ with the thione group of acrithion 2, forming an intermediate thioacridinium $-\mathrm{Hg}^{+}$ complex. This phenomena would polarize the $\mathrm{C}=\mathrm{S}$ bond and therefore facilitate nucleophilic attack by water at the electrophilic C9 position. Subsequently, the hydrolytic desulfurization is expected to form compound $\mathbf{1}$ - which is more fluorescent at the expense of poorly emitting acrithion 2 . In addition to the fluorescence amplification, the difference in the absorbance wavelengths between acrithion 2 and the desulfurization product 1 would also afford colorimetric naked-eye signaling of $\mathrm{Hg}^{2+}$.

\section{Results and Discussion}

Acrithion $\mathbf{2}$ is synthesized in good yield by treatment of readily available 10-methyl acridone 1 with $\mathrm{P}_{2} \mathrm{~S}_{5}$ in pyridine [59]

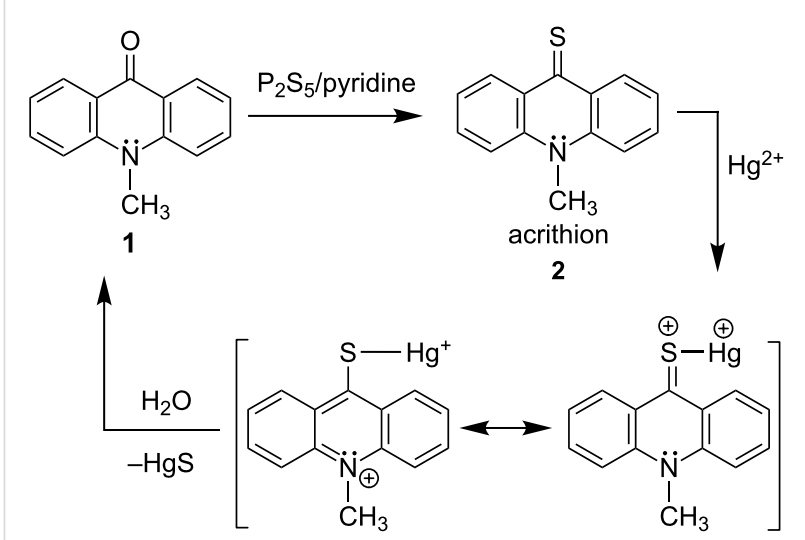

Scheme 1: Synthesis of acrithion 2 and its chemodosimeter mechanism for $\mathrm{Hg}^{2+}$ recognition.
(Supporting Information File 1). The optical sensitivities of acrithion 2 towards various biologically and environmentally important metal ions as their perchlorates were evaluated on the basis of UV-vis as well as fluorescence spectral responses. Acrithion $2\left(2.83 \times 10^{-5} \mathrm{M}\right)$ displayed absorption bands at 493 , 462 and $293 \mathrm{~nm}$ in DMSO- $\mathrm{H}_{2} \mathrm{O}(70: 30 \mathrm{v} / \mathrm{v})$ at $\mathrm{pH} 7.4(10 \mathrm{mM}$ HEPES buffer). As shown in Figure 1, the spectrophotometric titration of acrithion $2\left(2.83 \times 10^{-5} \mathrm{M}\right)$ with increasing $\mathrm{Hg}^{2+}$ induced a new blue-shifted maximum at $404 \mathrm{~nm}$, while the probe's maxima at 493 and $462 \mathrm{~nm}$ gradually diminished and disappeared at the limiting $2.83 \times 10^{-4} \mathrm{M}$ of $\mathrm{Hg}^{2+}$. At the limiting concentration of $\mathrm{Hg}^{2+}$, the final $\mathrm{UV}$-vis spectrum was essentially similar to that of $\mathbf{1}$ [60], an observation that supports the $\mathrm{Hg}^{2+}$-induced desulfurization of the probe [60]. An independent confirmation of $\mathbf{1}$ was also obtained from the ${ }^{13} \mathrm{C}$ NMR spectrum of the product isolated from the reaction of acrithion 2 with $\mathrm{Hg}\left(\mathrm{ClO}_{4}\right)_{2}$ in aqueous DMSO (Supporting Information File 1).

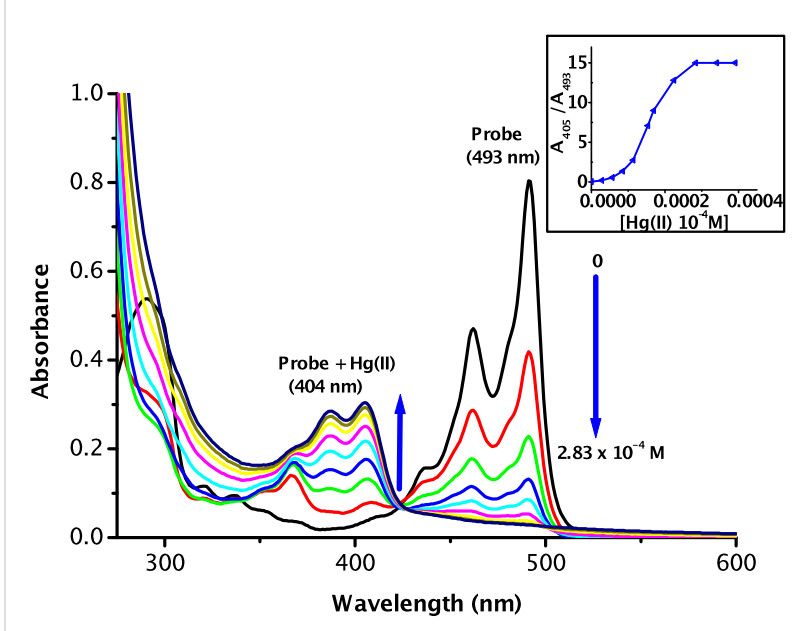

Figure 1: Spectrophotometric titration of acrithion $2\left(2.83 \times 10^{-5} \mathrm{M}\right)$ with $\mathrm{Hg}^{2+}\left(0-2.83 \times 10^{-4} \mathrm{M}\right)$ in $\mathrm{DMSO}-\mathrm{H}_{2} \mathrm{O}(70: 30 \mathrm{v} / \mathrm{v})$ at $\mathrm{pH} 7.4$.

As depicted in Figure 2, no detectable changes in the absorbance profile of acrithion 2 could be seen up on adding

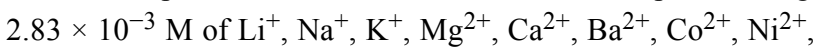
$\mathrm{Cu}^{2+}, \mathrm{Zn}^{2+}, \mathrm{Cd}^{2+}$, and $\mathrm{Pb}^{2+}$ even after $20 \mathrm{~min}$, implying the absence of substantive ground state interaction. On the other hand, the exposure of the probe to $\mathrm{Ag}^{+}$at $2.83 \times 10^{-3} \mathrm{M}$ led to partial reductions of the probe's maxima at 493 and $462 \mathrm{~nm}$, accompanied by the appearance of a new, weakly absorbing band at $347 \mathrm{~nm}$. However, unlike $\mathrm{Hg}^{2+}$, the desulfurization product 1 could not be detected with $\mathrm{Ag}^{+}$. Though it has not been investigated in detail, the findings mentioned above imply that the interaction of $\mathrm{Ag}^{+}$is not only relatively weaker, but also of a different nature than observed with $\mathrm{Hg}^{2+}$. The addition of $\mathrm{Hg}^{2+}$ turned the deep yellow solution of acrithion $\mathbf{2}$ into a color- 


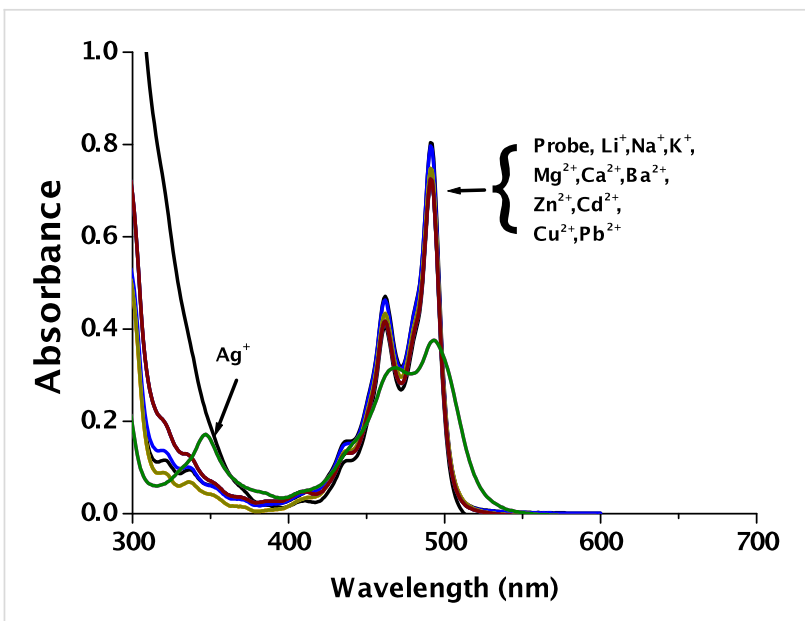

Figure 2: Spectrophotometric investigation of acrithion 2 $\left(2.83 \times 10^{-5} \mathrm{M}\right)$ with metal ions $\left(2.83 \times 10^{-3} \mathrm{M}\right)$ in $\mathrm{DMSO}-\mathrm{H}_{2} \mathrm{O}$ $(70: 30 \mathrm{v} / \mathrm{v})$ at $\mathrm{pH} 7.4$.

less one, permitting ready naked-eye detection of this ion. While weakly interacting $\mathrm{Ag}^{+}$induced only a slight dilution of the yellow color, no perceptible color modulations were noticeable with the several background metal ions which were examined (Supporting Information File 1).

Excitation of acrithion 2 at $404 \mathrm{~nm}$ in DMSO- $\mathrm{H}_{2} \mathrm{O}(70: 30 \mathrm{v} / \mathrm{v})$ at $\mathrm{pH} 7.4$ gave rise to a weak emission band at $424 \mathrm{~nm}$ with a quantum yield $\left(\Phi_{\mathrm{F}}\right)$ of 0.021 , calculated with respect to anthracene $\left(\Phi_{\mathrm{F}}=0.27\right)[61]$. Fluorimetric titration (Figure 3) revealed linear enhancements in the emission intensity with a significant 17 -fold enhancement observed at a limiting $5.1 \times 10^{-5} \mathrm{M}^{\circ} \mathrm{Hg}^{2+}[60]$. Based on the linear response observed in emission intensity with respect to increasing $\mathrm{Hg}^{2+}$ concentration, we calculated the limit of detection (LOD) of $\mathrm{Hg}^{2+}$ to be $1.06 \times 10^{-8} \mathrm{~mol} \mathrm{~L}^{-1}$ or $2.12 \mu \mathrm{g} \mathrm{L}^{-1}{\mathrm{of} \mathrm{Hg}^{2+}}^{2+}$ (Supporting Information File 1). Though, this LOD level of the

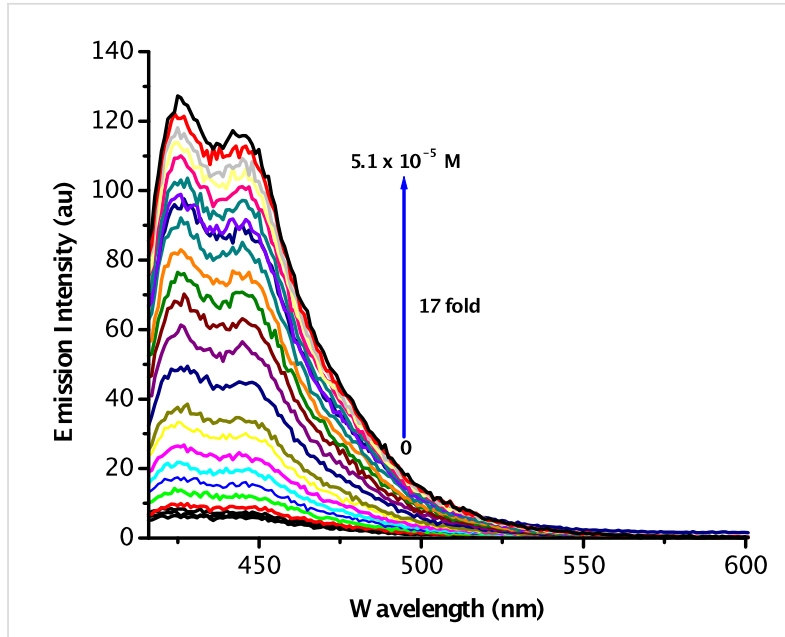

Figure 3: Fluorimetric titration of acrithion $2\left(2.5 \times 10^{-6} \mathrm{M}\right)$ with $\mathrm{Hg}^{2+}$ $\left(0-5.1 \times 10^{-5} \mathrm{M}\right)$ in DMSO- $\mathrm{H}_{2} \mathrm{O}(70: 30 \mathrm{v} / \mathrm{v})$ at $\mathrm{pH} 7.4$.

probe is unsuitable to measure $1 \mu \mathrm{g} \mathrm{L}^{-1}$ of $\mathrm{Hg}^{2+}$ - the lowest permission quantity in drinking water - however, there might be potential for measuring micromolar concentrations of $\mathrm{Hg}^{2+}$ in environmental samples with the probe.

In contrast to the sizeable fluorescence amplification observed with $\mathrm{Hg}^{2+}$, the weakly interacting $\mathrm{Ag}^{+}$induced only less marked emission enhancement of only 3 -fold at a concentration which was nearly 10 times the limiting concentration of $\mathrm{Hg}^{2+}$ (Supporting Information File 1). Consistent with their lack of ground state interaction, metal ions viz. $\mathrm{Li}^{+}, \mathrm{Na}^{+}, \mathrm{K}^{+}, \mathrm{Mg}^{2+}$, $\mathrm{Ca}^{2+}, \mathrm{Ba}^{2+}, \mathrm{Co}^{2+}, \mathrm{Ni}^{2+}, \mathrm{Cu}^{2+}, \mathrm{Zn}^{2+}, \mathrm{Cd}^{2+}$, and $\mathrm{Pb}^{2+}$ up to 100 equiv did not reveal any significant fluorescence modulations (Supporting Information File 1).

As shown in Figure 4, the addition of $\mathrm{Hg}^{2+}$ to a solution of acrithion 2 generated a brilliant blue fluorescence whereas other

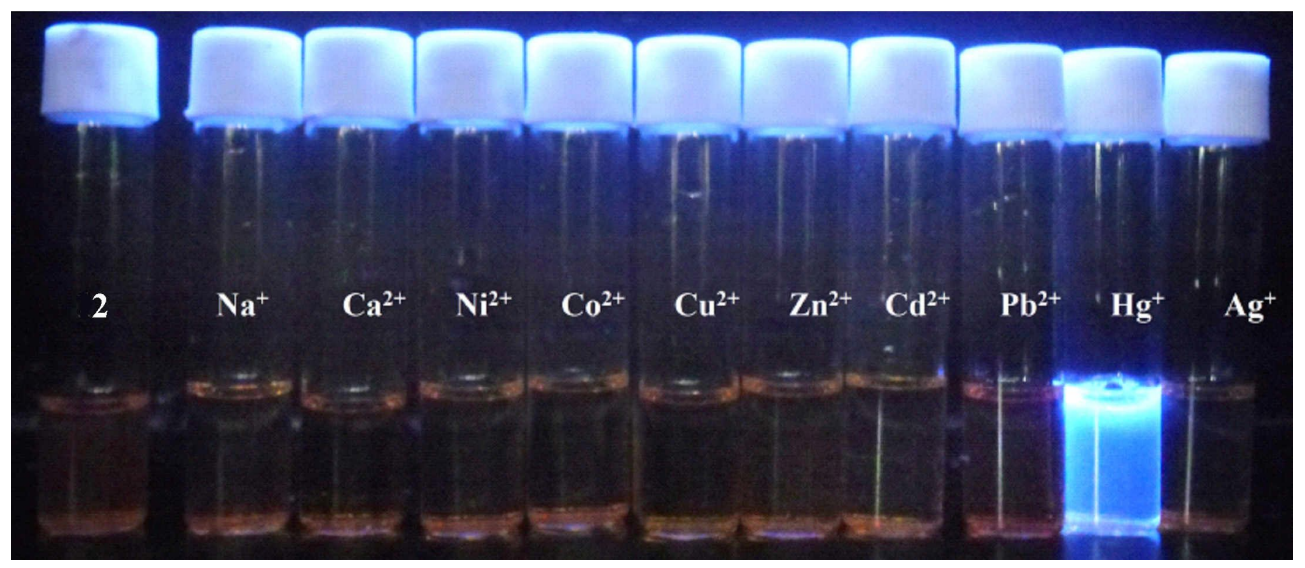

Figure 4: Changes in fluorescence of acrithion 2 upon addition of metal ions in DMSO- $\mathrm{H}_{2} \mathrm{O}(70: 30 \mathrm{v} / \mathrm{v})$ at $\mathrm{pH} 7.4$. 
metal ions showed no detectable fluorescence responses. To verify the high selectivity of $\mathrm{Hg}^{2+}$ over other metal ions, we first measured the fluorescence response of the probe $\left(2.5 \times 10^{-6} \mathrm{M}\right)$ in the presence of a matrix consisting of 100 equiv of each $\mathrm{Li}^{+}, \mathrm{Na}^{+}, \mathrm{K}^{+}, \mathrm{Mg}^{2+}, \mathrm{Ca}^{2+}, \mathrm{Ba}^{2+}, \mathrm{Co}^{2+}, \mathrm{Ni}^{2+}$, $\mathrm{Cu}^{2+}, \mathrm{Zn}^{2+}, \mathrm{Cd}^{2+}, \mathrm{Ag}^{+}$and $\mathrm{Pb}^{2+}$. The matrix gave rise to about 3 -fold fluorescence enhancement compared to that of the free probe. The addition of $\mathrm{Hg}^{2+}\left(5.1 \times 10^{-5} \mathrm{M}\right)$ to the matrix solution described above caused ca. 15-fold fluorescence enhancement, a value comparable to that induced by $\mathrm{Hg}^{2+}$ alone at the same concentration. This experiment (Figure 5) clearly demonstrates the superior chemodosimeter action of hazardous mercury ions in samples containing several background metal ions.

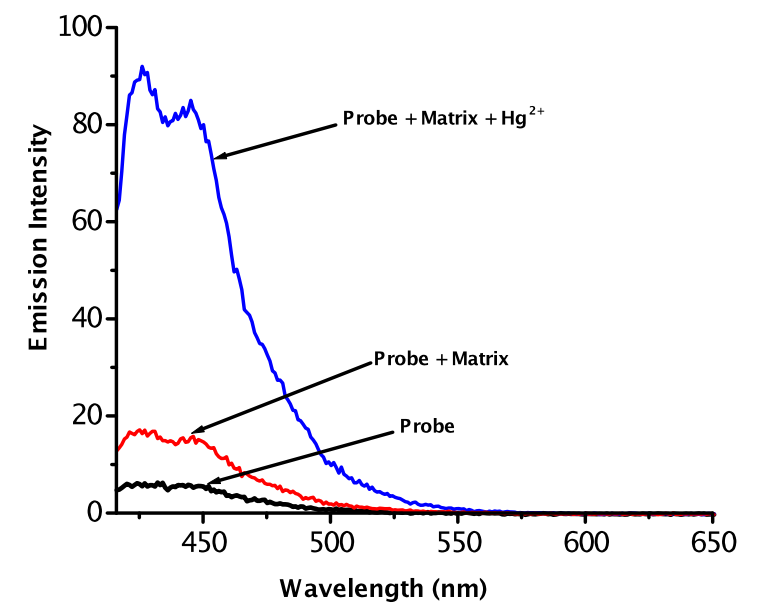

Figure 5: Emission spectra of acrithion $2\left(2.5 \times 10^{-6} \mathrm{M}\right)$, acrithion $2+$ matrix consisting of $2.5 \times 10^{-4} \mathrm{M}$ each of $\mathrm{Li}^{+}, \mathrm{Na}^{+}, \mathrm{K}^{+}, \mathrm{Mg}^{2+}, \mathrm{Ca}^{2+}$, $\mathrm{Ba}^{2+}, \mathrm{Co}^{2+}, \mathrm{Ni}^{2+}, \mathrm{Cu}^{2+}, \mathrm{Zn}^{2+}, \mathrm{Cd}^{2+}, \mathrm{Ag}^{+}$and $\mathrm{Pb}^{2+}$ and acrithion $2+$ matrix $+\mathrm{Hg}^{+2}\left(5.1 \times 10^{-5} \mathrm{M}\right)$.

In addition to the matrix experiment described above, we studied the effects of individual interferents on the fluorescence response of mercury ions. Therefore, the fluorescence spectra of the probe in the presence of individual metal ions $\left(2.5 \times 10^{-4} \mathrm{M}\right.$ each) without and with added merucury ions at $5.1 \times 10^{-5} \mathrm{M}$ were recorded. As shown in Figure 6, the background metal ions exhibited either none or insignificant perturbations on the selective fluorescence response observed upon adding mercury ions.

Next, to evaluate the response time, we plotted a time-dependent evolution of fluorescence with respect to the limiting concentration of $\mathrm{Hg}^{2+}$ at $20{ }^{\circ} \mathrm{C}$. As shown in Figure 7, a substantial gain in the emission intensity (ca. $75 \%$ of the total enhancement) is recorded under 20 min of contact time. Thereafter, the fluorescence enhancement occurs relatively slowly,

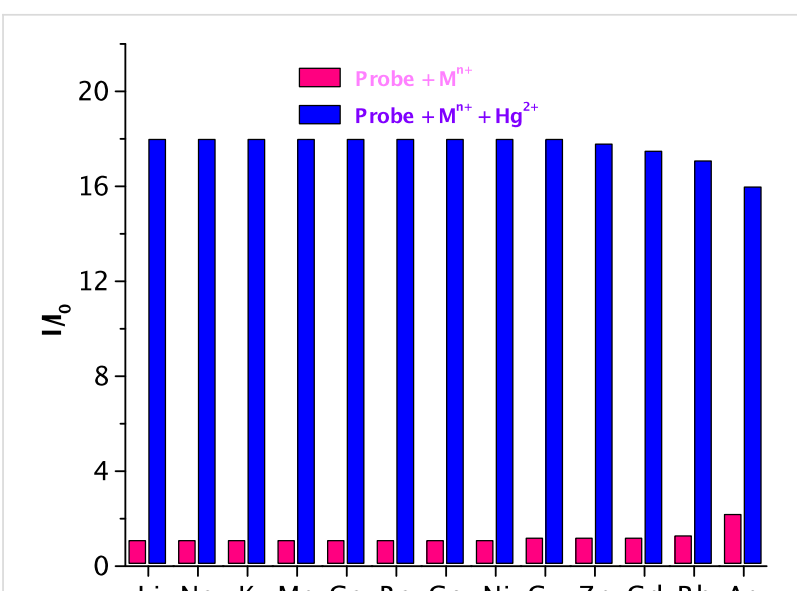

Li $\mathrm{Na} \mathrm{K} \mathrm{MgCa} \mathrm{Ba} \mathrm{Co} \mathrm{Ni} \mathrm{Cu} \mathrm{Zn} \mathrm{Cd} \mathrm{Pb} \mathrm{Ag}$

Figure 6: Fluorimetric response of acrithion $2\left(2.5 \times 10^{-6} \mathrm{M}\right)$ in the presence of background metal ions $\left(2.5 \times 10^{-4} \mathrm{M}\right.$ each $)$ in red and after addition of $\mathrm{Hg}^{2+}\left(5.1 \times 10^{-5} \mathrm{M}\right)$ in blue.

reaching an optimum value within ca. $30 \mathrm{~min}$ and then remaining steady beyond this point. The response time of acrithion 2 is comparable to many known $\mathrm{Hg}^{2+}$ chemodosimeters, however, this delayed time for $\mathrm{Hg}^{2+}$ signaling may limit its practical applications.

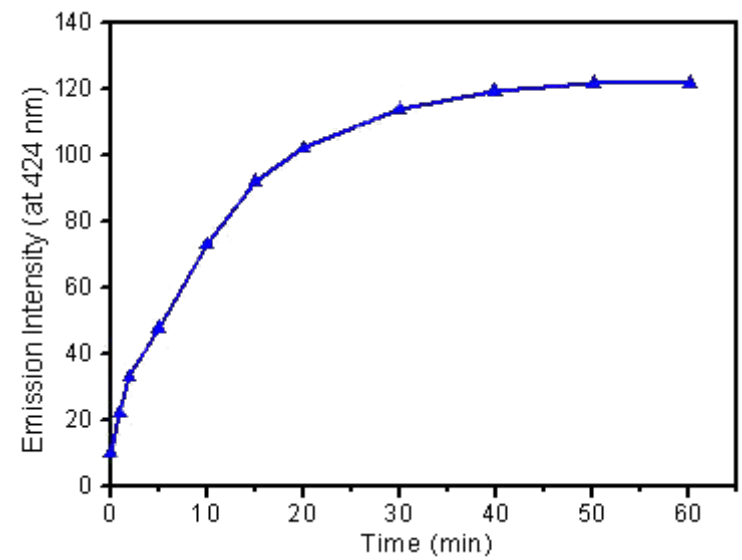

Figure 7: Time course plot of the change in emission intensity of acrithion 2.

\section{Conclusion}

In conclusion, 10-methylthioacridone constitutes one of the simplest and most easily accessible chemodosimeters affording dual colorimetric and fluorescence switch-on responses for the selective and sensitive targeting of toxic $\mathrm{Hg}^{2+}$. Other merits of the chemodosimeter include visible-light excitation and absence of significant interferences, especially from the competing $\mathrm{Ag}^{+}$, $\mathrm{Cu}^{2+}$ and $\mathrm{Pb}^{2+}$, the features which may prove conducive to $\mathrm{Hg}^{2+}$-sensing applications in certain circumstances. 


\section{Supporting Information}

\section{Supporting Information File 1}

Synthesis of acrithion 2, IR, ${ }^{1} \mathrm{H}$ NMR, and ${ }^{13} \mathrm{C}$ NMR data, experimental confirmation of 10-methylacridone, naked-eye detection and the determination of the limit of detection.

[http://www.beilstein-journals.org/bjoc/content/ supplementary/1860-5397-8-155-S1.pdf]

\section{References}

1. Valeur, B. Molecular Fluorescence: Principles and Applications; Wiley-VCH: Weinheim, Germany, 2002.

2. Czarnik, A. W. Fluorescent Chemosensors for lon and Molecule Recognition; American Chemical Society: Washington, DC, 1992. doi:10.1021/bk-1993-0538

3. Desvergne, J. P.; Czarnik, A. W. Chemosensors for lon and Molecule Recognition; NATO Asi Series, Series C; Kluwer Academic Publishers: London, 1997.

4. Suksai, C.; Tuntulani, T. Chem. Soc. Rev. 2003, 32, 192. doi:10.1039/b209598j

5. De Silva, A. P.; Gunaratne, H. Q. N.; Gunnlaugsson, T.; Huxley, A. J. M.; McCoy, C. P.; Rademacher, J. T.; Rice, T. E. Chem. Rev. 1997, 97, 1515. doi:10.1021/cr960386p

6. McKeown-Eyssen, G. E.; Ruedy, J.; Neims, A. A. J. Epidemiol. 1983, 118, 470

7. Davidson, P. W.; Myers, G. J.; Cox, C.; Shamlaye, C. F.; Marsh, D. O.; Tanner, M. A.; Berlin, M.; Sloane-Reeves, J.; Cernichiari, E.; Choisy, O.; Choi, A.; Clarkson, T. W. Neurotoxicology 1995, 16, 677.

8. Grandjean, P.; Weihe, P.; White, R. F.; Debes, F. Environ. Res. 1998, 77, 165. doi:10.1006/enrs.1997.3804

9. Clarkson, T. W.; Magos, L.; Myers, G. J. N. Engl. J. Med. 2003, 349, 1731. doi:10.1056/NEJMra022471

10. von Burg, R. J. Appl. Toxicol. 1995, 15, 483. doi:10.1002/jat.2550150610

11. Harada, M. Crit. Rev. Toxicol. 1995, 25, 1. doi:10.3109/10408449509089885

12. Marzouk, S. A. M.; Al-Ariqui, W. T.; Hassan, S. S. M. Anal. Bioanal. Chem. 2003, 375, 1186.

13. Grandini, P.; Mancin, F.; Tecilla, P.; Scrimin, P.; Tonellato, U. Angew. Chem., Int. Ed. 1999, 38, 3061. doi:10.1002/(SICI)1521-3773(19991018)38:20<3061::AID-ANIE3061>3 .0.CO;2-A

14. Krämer, R. Angew. Chem., Int. Ed. 1998, 37, 772. doi:10.1002/(SICI)1521-3773(19980403)37:6<772::AID-ANIE772>3.0. $\mathrm{CO} ; 2-\mathrm{Z}$

15. Zeng, H.-H.; Thompson, R. B.; Maliwal, B. P.; Fones, G. R.; Moffett, J. W.; Fierke, C. A. Anal. Chem. 2003, 75, 6807. doi:10.1021/ac0345401

16. Zhao, Y.; Zhong, Z. J. Am. Chem. Soc. 2006, 128, 9988. doi:10.1021/ja062001i

17. Quang, D. T.; Kim, J. S. Chem. Rev. 2010, 110, 6280. doi:10.1021/cr100154p

18. Nuriman; Kuswandi, B.; Verboom, W. Anal. Chim. Acta 2009, 655, 75. doi:10.1016/j.aca.2009.09.045

19. Kawakami, J.; Ohtake, R.; Miyamoto, R.; Nagaki, M.; Ito, S. Trans. Mater. Res. Soc. Jpn. 2008, 33, 9
20. Chae, M. Y.; Czarnik, A. W. J. Am. Chem. Soc. 1992, 114, 9704. doi:10.1021/ja00050a085

21. Dujols, V.; Ford, F.; Czarnik, A. W. J. Am. Chem. Soc. 1997, 119, 7386. doi:10.1021/ja971221g

22. Song, K. C.; Kim, J. S.; Park, S. M.; Chung, K.-C.; Ahn, S.; Chang, S.-K. Org. Lett. 2006, 8, 3413. doi:10.1021/ol060788b

23. Choi, M. G.; Kim, Y. H.; Namgoong, J. E.; Chang, S.-K. Chem. Commun. 2009, 3560. doi:10.1039/b905612b

24. Namgoong, J. E.; Jeon, H. L.; Kim, Y. H.; Choi, M. G.; Chang, S.-K. Tetrahedron Lett. 2010, 51, 167. doi:10.1016/j.tetlet.2009.10.111

25. Du, J.; Fan, J.; Peng, X.; Sun, P.; Wang, J.; Li, H.; Sun, S. Org. Lett. 2010, 12, 476. doi:10.1021/ol902590g

26. Yang, Y.-K.; Yook, K.-J.; Tae, J. J. Am. Chem. Soc. 2005, 127, 16760. doi:10.1021/ja054855t

27. Yang, X.-F.; Li, Y.; Bai, Q. Anal. Chim. Acta 2007, 584, 95. doi:10.1016/j.aca.2006.11.015

28. Wu, J.-S.; Hwang, I.-C.; Kim, K. S.; Kim, J. S. Org. Lett. 2007, 9, 907. doi:10.1021/ol070109c

29. Shi, W.; Ma, H. Chem. Commun. 2008, 1856. doi:10.1039/B717718F

30. Chen, X.; Nam, S.-W.; Jou, M. J.; Kim, Y.; Kim, S.-J.; Park, S.; Yoon, J. Org. Lett. 2008, 10, 5235. doi:10.1021/ol8022598

31. Liu, B.; Tian, H. Chem. Commun. 2005, 3156. doi:10.1039/B501913C

32. Lee, M. H.; Cho, B.-K.; Yoon, J.; Kim, J.-S. Org. Lett. 2007, 9, 4515. doi:10.1021/ol7020115

33. Lu, Z.-J.; Wang, P.-N.; Zhang, Y.; Chen, J.-Y.; Zhen, S.; Leng, B.; Tian, H. Anal. Chim. Acta 2007, 597, 306. doi:10.1016/j.aca.2007.06.057

34. Lee, M. H.; Lee, S. W.; Kim, S. H.; Kang, C.; Kim, J. S. Org. Lett. 2009, 11, 2101. doi:10.1021/ol900542y

35. Choi, M. G.; Ryu, D. H.; Jeon, H. L.; Cha, S.; Cho, J.; Joo, H. H.; Hong, K. S.; Lee, C.; Ahn, S.; Chang, S.-K. Org. Lett. 2008, 10, 3717. doi:10.1021/ol8013446

36. Song, F.; Watanabe, S.; Floreancig, P. E.; Koide, K. J. Am. Chem. Soc. 2008, 130, 16460. doi:10.1021/ja805678r

37. Sakamoto, H.; Ishikawa, J.; Nakao, S.; Wada, H. Chem. Commun. 2000, 2395. doi:10.1039/b007577i

38. Shiraishi, Y.; Maehara, H.; Ishizumi, K.; Hirai, T. Org. Lett. 2007, 9, 3125. doi:10.1021/ol0713133

39. Jung, Y.; Lippard, S. J. Chem. Rev. 2007, 107, 1387. doi:10.1021/cr068207j

40. Zhang, J. F.; Kim, J. S. Anal. Sci. 2009, 25, 1271. doi:10.2116/analsci.25.1271

41. Martinez, R.; Espinosa, A.; Tárraga, A.; Molina, P. Org. Lett. 2005, 7 , 5869. doi:10.1021/ol052508i

42. Kim, S. H.; Kim, J. S.; Park, S. M.; Chang, S.-K. Org. Lett. 2006, 8 , 371. doi:10.1021/ol052282j

43. Yoon, J.; Ohler, N. E.; Vance, D. H.; Aumiller, W. D.; Czarnik, A. W. Tetrahedron Lett. 1997, 38, 3845. doi:10.1016/S0040-4039(97)00768-5

44. Kim, Y.-H.; Youk, J. S.; Moon, S. Y.; Choe, J.-I.; Chang, S.-K. Chem. Lett. 2004, 33, 702. doi:10.1246/cl.2004.702

45. Rurack, K.; Kollmannsberger, M.; Resch-Genger, U.; Daub, J. J. Am. Chem. Soc. 2000, 122, 968. doi:10.1021/ja992630a

46. Youn, N. J.; Chang, S.-K. Tetrahedron Lett. 2005, 46, 125. doi:10.1016/j.tetlet.2004.11.003

47. Basheer, M. C.; Alex, S.; Thomas, K. G.; Suresh, C. H.; Das, S. Tetrahedron 2006, 62, 605. doi:10.1016/j.tet.2005.10.012

48. Moon, Y. S.; Cha, N. R.; Kim, Y. H.; Chang, S.-K. J. Org. Chem. 2004, 69, 181. doi:10.1021/jo034713m

49. Park, S. M.; Kim, M. H.; Choe, J.-I.; No, K. T.; Chang, S.-K. J. Org. Chem. 2007, 72, 3550. doi:10.1021/jo062516s 
50. Song, K.-C.; Kim, M. H.; Kim, H. J.; Chang, S.-K. Tetrahedron Lett. 2007, 48, 7464. doi:10.1016/j.tetlet.2007.08.070

51. Kim, S. H.; Song, K. C.; Ahn, S.; Kang, Y. S.; Chang, S.-K. Tetrahedron Lett. 2006, 47, 497. doi:10.1016/j.tetlet.2005.11.060

52. Móczár, I.; Huszthy, P.; Mezei, A.; Kádár, M.; Nyitrai, J.; Tóth, K. Tetrahedron 2010, 66, 350. doi:10.1016/j.tet.2009.10.076

53. Miyazi, H.; Sessler, J. L. Angew. Chem., Int. Ed. 2001, 40, 154. doi:10.1002/1521-3773(20010105)40:1<154::AID-ANIE154>3.0.CO;2G

54. Blázquez, M. T.; Muñiz, F. M.; Sáez, S.; Simón, L. M.; Alonso, Á.; Raposo, C.; Lithgow, A.; Alcázar, V.; Morán, J. R. Heterocycles 2006, 69, 73. doi:10.3987/COM-06-S(O)18

55. García-Garrido, S. E.; Caltagirone, C.; Light, M. E.; Gale, P. A. Chem. Commun. 2007, 1450. doi:10.1039/b618072h

56. Lin, C.; Simov, V.; Drueckhammer, D. J. J. Org. Chem. 2007, 72, 1742. doi:10.1021/jo062467j

57. Mashraqui, S. H.; Tripathi, S.; Betkar, R.; Chandiramani, M. Chem. Lett. 2010, 39, 650. doi:10.1246/cl.2010.650

58. Safarzadeh, A. A.; Condirston, D. A.; Verrall, R. E.; Steer, R. P. Chem. Phys. Lett. 1981, 77, 99. doi:10.1016/0009-2614(81)85608-4

59. Mizuyama, K.; Tominaga, Y.; Matsuda, Y.; Kobayashi, G. Chem. Pharm. Bull. 1979, 27, 2879. doi:10.1248/cpb.27.2879

60. Fukuzumi, S.; Ohkubo, K. J. Am. Chem. Soc. 2002, 124, 10270. doi:10.1021/ja026613o

61. Dawson, W. R.; Windsor, M. W. J. Phys. Chem. 1968, 72, 3251. doi:10.1021/j100855a027

\section{License and Terms}

This is an Open Access article under the terms of the Creative Commons Attribution License

(http://creativecommons.org/licenses/by/2.0), which permits unrestricted use, distribution, and reproduction in any medium, provided the original work is properly cited.

The license is subject to the Beilstein Journal of Organic Chemistry terms and conditions:

(http://www.beilstein-journals.org/bjoc)

The definitive version of this article is the electronic one which can be found at: $\underline{\text { doi: } 10.3762 / \text { bjoc. } 8.155}$ 